\title{
The Perception of the External Investment Environment of South Africa: The Case of Chinese SMEs FDI
}

Emmanuel Fru Ngam*

Department of Management, College of Business, Catholic University Institute of Buea (CUIB), Cameroon

\begin{abstract}
The purpose of this paper is to investigate how the Chinese SMEs in the Free State Province (FSP) perceive the external environment of doing business in South Africa and identifying the external environmental factors impacting foreign businesses investing in South Africa. A standard questionnaire was designed and self-administered to Chinese SMEs operating in different industries and towns in the Free State province. A total of 96 Chinese SMEs owners participated and the data obtained was analysed using descriptive statistics, frequency distribution tables and T-tests. Exploratory factor analysis identified four major external environmental factors (economic, political/institutional, sociocultural and legal systems factors) which included 36 sub-factors or items. The research findings showed that the Chinese SMEs have a negative perception about the external business environment of South Africa as they perceive the political/institutional factors (3.31), socio-cultural factors (3.05) and the legal system (3.20) as negative while the economic factors (4.01) are perceive as neutral. Crime, theft, security and xenophobia were being perceived the most negative sub-factors/items. Also external factors such as crime, corruption, labour regulations and xenophobia were being reckoned as the main external factors severely impacting the foreign businesses in SA.
\end{abstract}

\section{Keywords: External environmental factors; FDI; SMEs}

\section{Introduction}

The climate for investment is determined by the interplay of a whole set of factors such as political, economic, social, technological and legal (PESTLE) factors, which has a bearing on the operations of a business [1]. Theories supporting FDI in developing countries argue that the recipient countries need to fulfil some basic preconditions like a good macroeconomic policy, adequate tax systems and stable regulatory practices, if they want to create a satisfactory environment for investment. Additionally, the Ownership, Location and Internalization (OLI) theory which are generally viewed as the preeminent theoretical framework for foreign direct investment decisions [2] do take the PESTLE factors in to consideration when deciding to go internationally [3]. This therefore implies that for countries to attract FDI, they need to provide a favourable external environment which consists of the PESTLE factors.

Moreover, the investment experiences in the African countries show that free trade/outward-orientation alone is not sufficient to ensure FDI inflows. Similarly, the African continent has a high degree of uncertainty which makes investors reluctant to invest in Africa despite its enormous profitable opportunities [4]. This therefore raises the question about the effect of the external environment of the African continent on attracting FDI.

According to the World Economic Forum's (WEF) Global Competitiveness report for 2015/16, South Africa's environmental competitive position has dropped further down the order as it is now ranked $56^{\text {th }}$ out of 144 countries as compared to its $45^{\text {th }}$ position in 2009/10. This implies that South Africa's environmental competitiveness has decreased. The Global Competitiveness index is based on 12 pillars of competitiveness, namely: institutions, infrastructure, macroeconomic stability, health and primary education, higher education and training, market efficiency, labour market efficiency, financial market sophistication, technological readiness, market size, business sophistication and innovation. The Global Competitiveness report for 2015/16 further noted that the five most problematic factors for doing business in South Africa are restrictive labour regulations, inefficient government bureaucracy, inadequate supply of infrastructure, Policy instability and Inadequately educated workforce [5].

Nevertheless, South Africa remains the highest ranked country in Sub-Saharan Africa. Its strength is the advanced financial market development and the market size it possesses. This is so as they are ranked $12^{\text {th }}$ and $29^{\text {th }}$ respectively by the Global Competitiveness report (WEF, 2010:302). South Africa also received fair rankings in more complex areas such as the Institution (43); goods market efficiency (38), business sophistication $\left(33^{\text {th }}\right)$ and innovation (38th). On the other hand, South Africa is faced with a number of obstacles to competitiveness such as the labour market which is ranked a low $107^{\text {th }}$ due to its lack of flexibility. This lowly ranked level could also be attributed to the lack of skilled labour and the excess labour disputes and strikes which are not good for FDI flows. In addition, the higher education and training in SA which is ranked at 83 could be at risk as the university enrolment rate is only $15 \%$. The greatest concern, however, remains the health and primary education as they are ranked $126^{\text {th }}$ out of 140 countries, due to high rates of communicable diseases and poor health such as HIV.

For Africa to improve its investment climate, it has to have a favourable FDI regime and competitive factors of production. A favorable FDI regime requires a stable, efficient, and service-oriented environment that welcomes investors into most economic activities without discrimination. Modern legal and intellectual property rights, effective competition policies, a strong judiciary and minimum bureaucratic harassment are all important to attract foreign investors. The competitive factors of production are the crucial determinants

*Corresponding author: Emmanuel Fru Ngam, M.Com, Department of Management, College of Business, Catholic University Institute of Buea (CUIB), Buea, Cameroon, Tel: 00237678518823; E-mail: efngam@gmail.com

Received June 05, 2017; Accepted August 01, 2017; Published August 10, 2017

Citation: Ngam EF (2017) The Perception of the External Investment Environment of South Africa: The Case of Chinese SMEs FDI. J Bus Fin Aff 6: 282. doi: 10.4172/2167-0234.1000282

Copyright: (c) 2017 Ngam EF. This is an open-access article distributed under the terms of the Creative Commons Attribution License, which permits unrestricted use, distribution, and reproduction in any medium, provided the original author and source are credited. 
of FDI as they no longer mean just cheap raw labour and basic infrastructures. Today they require adaptable labour skills, sophisticated supplier networks and flexible institutions. Tax incentives can enhance a country's attractiveness but if other factors are unfavorable, they will be insufficient to significantly increase inflows of FDI.

\section{Research problem}

The South African government has endeavoured to create a stable environment for foreign direct investment with various policy amendments. This is a step in the right direction. However, in its quest to address the ills of the apartheid era and to 'level the playing fields', the government has adopted certain policies that tend to keep investors away. Of course, certain measures are necessary to readdress imbalances created in the past, but it seems that the right to regulate the economy in the national interest may clash with the desires and expectations of investors [6].

It is significant to emphasize that the above arguments are complementary rather than mutually exclusive or antagonistic. They show that Africa needs (a) increased investment for higher and sustained growth; and (b) increased productivity of its investment (in terms of domestic and foreign exchange returns) through increased capacity utilization, skilled and technological development as well as other supporting national, regional and international policy measures [7].

The argument of this study is that there are factors in the business environment that influence the investment decision of foreign SMEs either positively or negatively. Understanding how the existing foreign SMEs operating in South Africa perceive the external environmental factors will be vital in improving the business environment and thus attracting more foreign SMEs. This research will analyse the various factors in the business environment that scare away foreign investors and will suggest how to improve the external business environment so that more foreign investors can be attracted to boost the economic development. Likewise, investigating the external business environment of South Africa will be beneficial to both the RSA government and the investors as they will better understand the South African investment climate.

\section{Research objective}

The main objective of this paper is to investigate how the Chinese SMEs in the Free State Province (FSP) perceive the external environment of doing business in South Africa and identifying the external environmental factors impacting foreign businesses operating in South Africa.

\section{Literature Review}

The external environment for FDI plays a major role in promoting market-led growth and reducing poverty. Reducing poverty and improving living standards depends upon broad-based economic growth, which will only take place when firms improve worker productivity by investing in human and physical capital and technological capacity i.e., investing in knowledge, equipment and organizational structure. But firms will only invest when the investment environment is favorable [8].

For most of the 1980s and the first part of the 1990s, low or declining GDP growth, combined with rapid population increases, brought about widespread deterioration of socio-economic conditions in Africa. Consequently, while per capita income increased in other developing regions between 1980 and 1995, Africa experienced an average decline of 15 percent during the same period, with an estimated
40 to 49 percent of the population living in absolute poverty (especially in sub-Saharan Africa) (World Bank, 2003) [9]. After the mid-1980s, it was clear that comprehensive and credible macroeconomic reform and adjustment programs were needed to stem the deteriorating economic and social conditions. This led a number of countries to pursue reform programs, with support from bilateral and multilateral development agencies. The reforms aimed at stimulating economic growth by putting in place incentives and measures that generate more savings, investment and exports. Anchored on economic liberalization, the reforms emphasized the more efficient functioning of markets and the increase of foreign capital flow in Africa [7].

FDI is an important determinant of economic growth and development in developing countries. Studies have shown that the creation of adequate investment environment facilities increase trade and investment activities which are crucial for long-term growth [1]. Internationally, businesses are continuously searching for new markets or countries with cheaper manufacturing costs to relocate their production. According to Wei [10], low production costs and abundant labour supply in the host country were the two most important benefits sought from a FDI, while law and regulations were perceived as major constraints. However, Africa with the abundant resources and the availability of cheap labour has not attracted its fair share of FDI. Luiz [11] suggested that part of the reason is that the risk of doing business on the continent is seen as too high because of the perceived high levels of political and policy instability. Loss of trust and confidence has a huge influence on any FDI decision and also the host country government's policies and attitude affect FDIs [10].

\section{Main Factors}

\section{Political factors}

Political instability in a host country changes the "rules of the game" under which businesses operate and that impact on the profits and future of FDI inflows. Political factors like change of government, attitudes of opposition parties, transparency in bureaucracy, corruption, terrorism etc., are seriously considered by investors in their pre-investment decisions. Companies are often affected by two main types of political changes; changes in the regime under which it operates or changes in the political stability of the country. The regime is considered to be the rules under which the economy, including the foreign firms operate in the country. Political instability affects corporations both directly and indirectly. Companies are directly affected because government instability often leads to administrative paralysis while they will be affected indirectly because the political instability often leads to changes in the regime. In extreme cases, companies are forced to leave the country [12]. It can therefore be hypothesized that the investment in a country can decrease when a country is unstable and increase when stable.

Some African countries experience political instabilities such as high incidence of wars, frequent military interventions in politics, and religious and ethnic conflicts, thus making most investors to perceive the entire continent, though wrongly, as unstable for investment purposes. Nevertheless, the fact that political instability is contagious and many African countries are interdependent has not helped matters in providing an attractive environment for FDI [13].

\section{Economic factors}

The economic factor is a huge environmental factor that influences how and why a foreign investor should invest abroad. In Sub-Sahara Africa (SSA), it is widely regarded that economic factors pose a bigger 
constraint to FDI in the region than the political factors. Issues such as education, quality human resource, health and infrastructure are said to be deteriorating in most countries in the SSA over the years and are now below standards compared to other countries in other developing areas. However, with such fading education and health systems, weak physical infrastructures, poor human resource and lack of back up services for enterprises, it will always be difficult to improve the competitiveness of Africa's investment climate [14]. Other economic factors that will have an impact on investors' decision making about a host country environment are: tariffs, openness to trade, trade barriers, exchange rate and inflation rates. High protective trade barriers make exports by firms to a potential host country uncompetitive [15].

\section{Technological factors}

With the world evolving around rapid technology advancement, countries with high technological capacity and man power are capable of attracting more FDI. The state of a country's physical and technological infrastructure is a significant determinant of transaction costs and of a country's suitability as an export base for competing world markets [16].

\section{Legal and regulatory factors}

Legal and regulatory policies are critical to providing the right environment and incentives at the national, regional and local levels. The policy framework of FDI in Africa is getting better over the years even though the FDI environment is still inadequate to attract high quality, efficient-seeking "globalising" FDI. This is so as the policy framework still suffers from a number of deficiencies such as barriers to entry which still exists in some countries as certain sectors are reserved for domestic firms only. Also, the registration procedures in some sub-Sahara African countries are cumbersome for foreign investors hence increasing their transaction cost. This is a typical situation in Cameroon where there is a substantial amount of paper work the investor has to go through before starting a business operation and the foreign investment must have $35 \%$ local equity [14].

\section{Social factors}

Social factors in this context refer to all other factors which are not political, economic, technological and legal. They refer to issues such as crime, security, labour issues, bureaucracies etc. Corruption is one of the greatest obstacles to economic and social development, as corruption undermines development by distorting the rule of law and weakening the institutional foundation on which economic growth depends. Corruption also stifles private sector growth and hurts the poor because it diverts public services from those who need them most. Corruption adversely affects various aspects of business operation from start-up to regular business transactions and can easily deter investors. This is supported by modern empirical researches that have proven the measures of corruption to be significantly and negatively related to FDI inflows [17]. Labour disputes also have a huge influence on foreign investors' decision making as foreign investors become less attractive to host countries with greater incidence or severity of industrial disputes or strikes [18].

Creating an external environment conducive for FDI is of utmost importance in attracting FDIs. External environmental factors such as political, economic, socio-cultural, technology and legal (PESTLE) factors have a huge influence on attracting FDI. Cheap manufacturing costs and an abundance of labour are some of the key drivers for attracting FDI, while an unfavourable political, regulatory and economic environment increase the risk and limit the flow of
FDI to a country. It is also important to note that these constraints in the external environment do not only impact on FDI, but also have negative consequences for local businesses. Issues such as crime, corruption, labour regulations and unions, volatility of exchange rate, stability of government and taxes are major contributors to the low levels of entrepreneurial activity. Therefore, the African leaders must realise that they have a serious and pressing obligation to address the problems in their external environment, not only to attract FDI, but to create an environment that is conducive for doing business in Africa.

\section{Methodology}

This study was a cross-sectional study, using a pilot study and the survey method to collect data on how Chinese SMEs investors perceive the external investment environment of South Africa. The empirical study was approached from the perspective of a valid research design through definition of the study population, the incorporation of suitable measuring instrument and reliable techniques for data analysis as stipulated in Cooper and Schindler [19]. The measuring instrument was designed to measure the external environmental variables (the business environment) that can impact on foreign SMEs investing in the FSP. For this reason, a standard questionnaire was designed after a thorough literature review of the business environment and foreign SMEs investments. Data was gathered through self-administered questionnaires.

The researcher selected a sample of respondents from the Chinese business population using a simple random sampling method and a nonprobability snowball sampling method [20]. These methods were used because it was the most practical procedure given the fact that accurate records on the location, number and size (in terms of employment and financial measures) of Chinese SMEs were not available in the databases of the Free State and other SMEs support mechanisms in the country. The Chinese business population was used in this survey because most of the foreign SMEs in the Free State province are owned by the Chinese. The questionnaire focused predominantly on how the Chinese SMEs perceive the external environment.

Of the 148 Chinese businesses that were approached, only 96 Chinese SMEs were considered in the study as those were the questionnaires that were returned fully completed thus, giving a valid response rate of $65 \%$ of Chinese SMEs who participated fully in the study. The Demetra sample size calculator was also used to estimate the sample size using a confidence interval of $10 \%$ and a confidence level of $95 \%$ to obtain a sample size of 96 . This therefore indicates that the sample size used in this study (96) is the same as the sample size estimated by the Demetra sample size calculator. Exploratory factor analysis was used to refine the research problem and enhance the validity of the research. In addition, the statistical analyses include descriptive statistics, frequency tables and T-tests. Reliability was tested using the Cronbach's Alpha.

\section{Results}

\section{Profile of respondents}

The 96 respondents that participated in the study were a mixture of Chinese SMEs from different industries and from different towns in the Free State province such as Bloemfontein, Botshabelo, ThabaNchu, Welkom, Ladybrand, QwaQwa and Sasolburg. The respondents in these towns were well representative of all the major municipalities in the Free State. Of the 96 respondents, the majority were in the retail/wholesale sector (39\%) while $34 \%$ and $27 \%$ were operating in the manufacturing and other business sectors respectively. The 
average business experience of the respondents is 8 years and $25 \%$ of the respondents had been operating for 11 or more years. This means the respondents in the study have sufficient experience of the business environment of South Africa and are more likely to give objective responses to the questions. Likewise, $40 \%$ of the respondents had operated a business in China before with $11 \%$ still operating a business in China. Also, 19\% of the respondents had operated a business in other country other than China, while $14 \%$ have other branches or businesses in South Africa. In general, $52 \%$ of the respondents have been operating for 6 or less years while $48 \%$ of the respondents have been operating for more than 6 years.

With regards to the size of the Chinese SMEs based upon the number of employees, $41 \%$ of the respondent had 10 or less employees as compared to $59 \%$ who had more than 10 employees. The respondents have on average 25 employees. Majority of the respondents (66\%) said they will invest again in South Africa if they were to make a decision today while $34 \%$ said they will not invest again. Crime (52\%), labour union (27\%), labour strike (15\%) and cost of labour (6\%) were the main reasons for the respondents who said they will not invest again. Also, $11 \%$ of the respondents have experience xenophobic attacks, $86 \%$ have suffered from crime and $20 \%$ have lost business because of the BEE policy.

\section{Major external factors impacting Chinese SMEs}

The results in Table 1 show the mean scores of how the major external factors impact Chinese SMEs. The respondent did answer the questions on a 7-point Likert scale but in Table 1, the responses have been grouped into three parts; negative, neutral and positive. Respondents who indicated 1 and 2 were grouped as negative, 3 to 5 as being neutral and 6 to 7 as being positive. This was done in order to get a true picture of those who were negative, neutral or positive.

Most of the respondents distinctively indicated that political stability and infrastructure have a positive impact on their businesses. Majority of the respondents indicated that corruption and crime were impacting their businesses negatively. This therefore shows that the government is failing to control corruption and fight crime as these issues continue to affect the running of businesses in the RSA. Also, the respondents were quick to point out that xenophobia and labour regulations were affecting their businesses. Thus, it is obligatory for South Africa to address the problems of labour regulations, xenophobia, corruption and crime if they want to keep the existing foreign businesses or attract more FDI.

\begin{tabular}{|c|c|c|c|c|c|}
\hline & Negative & Neutral & Positive & Mean & Rank \\
\hline $\begin{array}{c}\text { Factors impact on your } \\
\text { business }\end{array}$ & $1-3$ & 4 & $5-7$ & 3.55 & \\
\hline Political stability & 17 & 15 & 53 & 4.93 & 1 \\
\hline Infrastructure (Roads, etc) & 13 & 19 & 54 & 4.85 & 2 \\
\hline Economic conditions & 34 & 23 & 38 & 4.01 & 3 \\
\hline Ethics & 24 & 49 & 23 & 3.84 & 4 \\
\hline Government regulations & 33 & 39 & 22 & 3.77 & 5 \\
\hline Legal systems & 30 & 49 & 17 & 3.69 & 6 \\
\hline Labour regulations & 54 & 33 & 9 & 2.89 & 7 \\
\hline Xenophobia & 68 & 20 & 7 & 2.68 & 8 \\
\hline Corruption & 72 & 20 & 4 & 2.54 & 9 \\
\hline Crime & 82 & 4 & 10 & 2.35 & 10 \\
\hline
\end{tabular}

7 point Likert scale: 1-very negative and 7-very positive.

Table 1: Major external factors impacting Chinese SMEs.

\section{Analysis of the external environmental factors}

In order for the researcher to get the respondents' feelings about the external environment in South Africa, the researcher posed several external environmental factors for the respondents to indicate how they perceive each of the factors. The respondents were to answer the questions on a 7-point Likert scale ranging from 1 -very negative to 7 -very positive with 4 being the neutral value. The external environmental factors were divided into four groups i.e., economic, political/institutional, socio-cultural and legal factors. Before proceeding to look at how the respondents perceive the external environment, Cronbach's alpha was used to measure the reliability of the different environmental factors under the four main groups or factors; economic, political/institutional, socio-cultural and legal factors. The essence of Cronbach's alpha is to see whether the various factors in each specific group relate to each other. Cronbach's alpha of greater than 0.7 indicate a great reliability of the data.

There were 8 items under the economic factors and the Cronbach's alpha was 0.719 , thus indicating the reliability of the economic factors. The Cronbach's alpha for political/institutional factor was 0.669 . This shows the items under political/institutional factors are not all that closely related. To improve the reliability, the item "stable government" was deleted from the grouping and this did better the Cronbach's alpha for political/institutional factors to 0.78 . Hence, only five items were used to determine how the respondents feel about the political/ institutional environment. Moreover, the Cronbach's alpha for socio-cultural and legal system is 0.803 and 0.815 , respectively, thus indicating the reliability of the socio-cultural and legal system factors.

\section{Chinese SMEs perception of the external environmental factors in South Africa}

Figure 1 shows how the respondents perceive the four main external environmental factors; economic, political/institutional, socio-cultural and legal factors on a 7-point Likert scale ranging from 1-very negative to 7 -very positive with 4 being the neutral value.

Figure 1 shows that the respondents perceive the economic factors to be neutral or slight positive while they perceive the political/ institutional, socio-cultural and legal factors to be negative. Therefore, overall, the external environment of South Africa is been perceive as negative or poor by the Chinese SMEs operating in the Free State province. Thus, for South Africa to attract more productive FDI that will bring development and economic growth, the business environment must be made more attractive to both the existing foreign businesses and FDI.

Table 2 illustrates the perception of the respondents with regard to the individual economic factors in the business environment, with

\begin{tabular}{|c|c|c|c|c|c|c|}
\hline & Negative & Neutral & Positive & Mean & $\begin{array}{c}\text { Rank } \\
\text { mean }\end{array}$ & $\begin{array}{c}\text { Std } \\
\text { Dev }\end{array}$ \\
\hline Economic Factors & $1-3$ & 4 & $5-7$ & 4.01 & & 1.41 \\
\hline Good Financial / Banking & 16 & 23 & 51 & 4.85 & 1 & 1.55 \\
\hline Economic growth & 19 & 19 & 51 & 4.63 & 2 & 1.36 \\
\hline Exchange rate & 32 & 27 & 36 & 4.14 & 3 & 1.53 \\
\hline Competition & 32 & 29 & 33 & 3.99 & 4 & 1.36 \\
\hline Taxes & 30 & 48 & 18 & 3.82 & 5 & 1.26 \\
\hline Interest rate & 33 & 37 & 25 & 3.81 & 6 & 1.23 \\
\hline Access to credit & 35 & 36 & 22 & 3.63 & 7 & 1.42 \\
\hline Inflation rate & 57 & 21 & 18 & 3.23 & 8 & 1.54 \\
\hline
\end{tabular}

7 point Likert scale: 1 -very negative and 7-very positive.

Table 2: Perception of the economic factors in the business environment. 
Perception of the External Environmental Factors

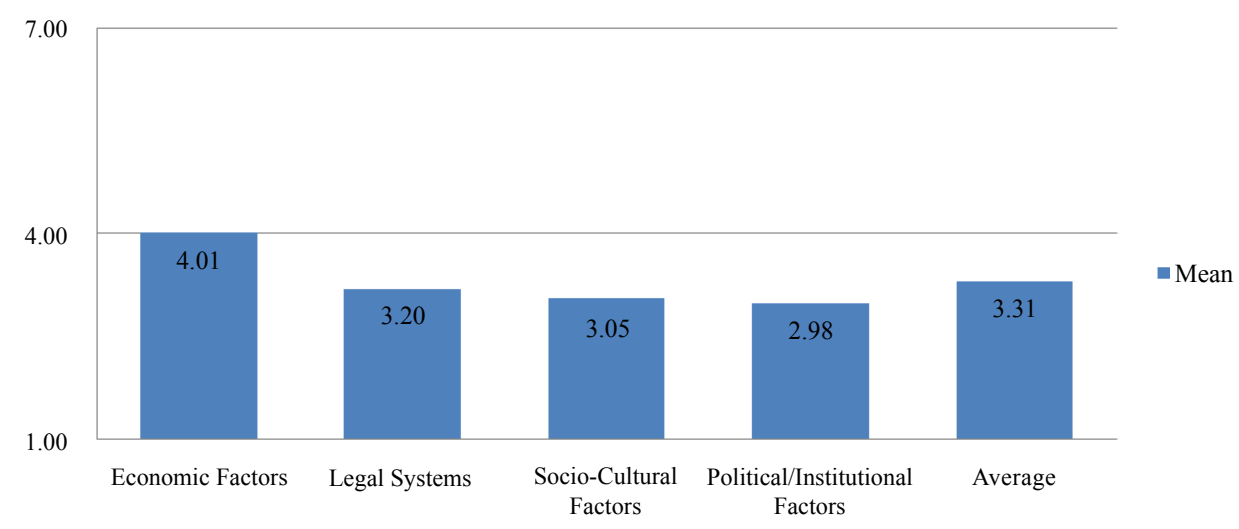

Figure 1: Perception of the external environmental factors.

\begin{tabular}{|c|c|c|c|c|c|c|}
\hline & Negative & Neutral & Positive & Mean & $\begin{array}{c}\text { Rank } \\
\text { mean }\end{array}$ & $\begin{array}{c}\text { Std } \\
\text { Dev }\end{array}$ \\
\hline $\begin{array}{c}\text { Political/Institutional } \\
\text { Factors }\end{array}$ & $1-3$ & 4 & $5-7$ & 2.98 & & 1.53 \\
\hline Start-up Documentation & 40 & 31 & 25 & 3.75 & 1 & 1.37 \\
\hline $\begin{array}{c}\text { Tax regulations } \\
\begin{array}{c}\text { Regulations on import of } \\
\text { goods }\end{array}\end{array}$ & 53 & 44 & 17 & 3.74 & 2 & 1.07 \\
\hline $\begin{array}{c}\text { Labour disputes and } \\
\text { strikes }\end{array}$ & 78 & 9 & 8 & 2.17 & 4 & 1.57 \\
\hline Labour unions & 79 & 8 & 9 & 2.10 & 5 & 1.63 \\
\hline
\end{tabular}

7 point Likert scale: 1-very negative and 7-very positive.

Table 3: Perception of the political/institutional factors in the business environment.

their mean ranging from 1 for very negative to 7 for very positive and 4 being the neural value. The responses were grouped into three groups; 1-3 for negative, 4 for neutral and 5-7 for positive.

Most of the respondents were positive about the financial/ banking system and the economic growth but were negative about the inflation rate. The World Economic Forum (WEF) through its Global Competitiveness report ranked the financial market development in South Africa at $12^{\text {th }}$ out of 140 countries [5]. This therefore shows that the financial and banking system in South Africa is of international standards. The respondents were slightly positive about the economic growth (4.63) of South Africa. This is probably because there have being just a slight decrease in the GDP in the past 3 years as the GDP in 2013, 2014 and 2015 has being 6.704, 6.621 and 6.071, respectively (South Africa Economic Outlook, 2017) [21].

Also, a small majority of the respondents (36) perceive access to credit to be neutral even though its total mean is below the neutral value 4. The respondents also indicated a mean of 3.99 for the competition level which implies that they are slight neutral about the environmental competitiveness of South Africa. To add, the respondents were slightly negative towards interest rate and taxes as they responded with a mean of 3.81 and 3.82, respectively. However, considering all the economic factors together, the respondents were neutral or slightly positive about the economic factors.

Table 3 shows the respondents opinion about the political/ institutional environment in South Africa. The 7-point Likert scale was divided into three main categories; negative, neutral and positive. Respondents who indicated 1 to 3 were grouped as negative, 4-neutral and 5 to 7 as positive.
Table 3 reveals that the respondents are having very negative perceptions about the political/institutional factors as the average mean of 2.98 , is well below the neutral value 4 . For each of the five items under the political/institutional factors, most of the respondents responded negatively. These responses show that the labour market/ regulations are one of the main factors hindering foreign investors in South Africa. Having a well-functioning labour market is vital in redressing the historical inequalities and to establish a vibrant and globally competitive economy. However, Clarke et al. [8] commented that the labour market of South Africa is too rigid on both the hiring and firing indices and may be interpreted as an institutional weakness. It is thus more costly and more difficult to hire and fire workers in South Africa than in most of other competitive economies.

Also, the five issues under political/institutional factors are very much under the control of the government of the RSA. Therefore, as the respondents perceive all five factors negatively, it means that the government is not performing their services properly. Furthermore, realizing a negative perception about the political/institutional environment implies that South Africa has to step up its start-up documentation processes, as well as improve its tax, export and labour regulations if it wants to attract more FDI or keep the existing ones operating in the RSA.

Figure 2 below show how the respondents perceive the various socio-cultural factors in the external environment.

A 7-point Likert scale was used, ranging from 1 for very negative value to 7 for very positive value and a mean value of 4 as the neutral value. The respondents experiences were quite different as it ranges from slightly positive for infrastructure (4.99) and telecommunication (4.99) to very negative for crime (1.70). Crime is viewed as very negative by the respondents and it had a very small standard deviation 1.31 , implying how unanimously the respondents felt about crime in South Africa. Couple with this, it was earlier shown that $86 \%$ of the respondents had suffered from crime. The level of crime and violence in South Africa is very high, ranking at 131 out of 140 countries according to the Global Competitiveness report for 2015/16 [5]. This confirms how severely the level of crime is impacting businesses and the quality of life in South Africa.

Theft (2.01), security (2.11) and xenophobia (2.28) were also negatively perceived by the respondents. The respondents perceive theft very negatively because most of them had experience workers trying to 


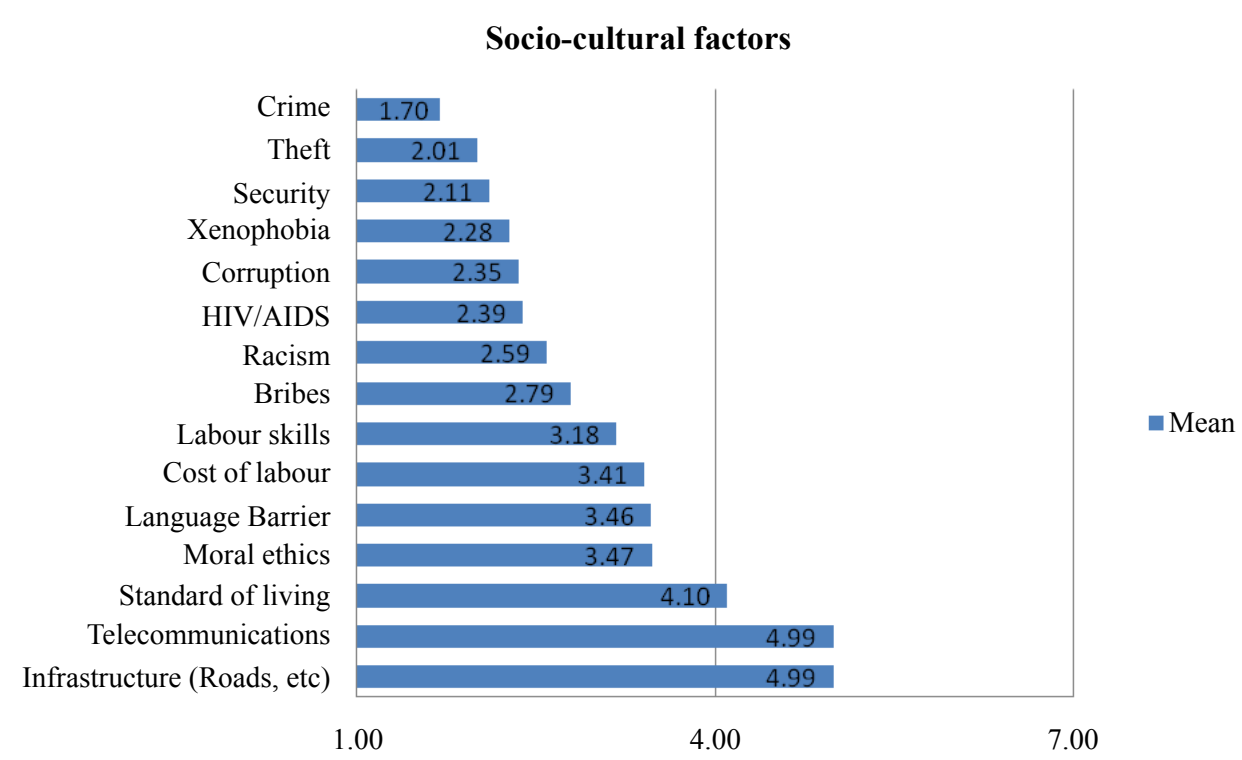

Figure 2: Perception of the socio-cultural factors in the business environment.

steal from their businesses. This is not good for the RSA as well as from the perspective of attracting more FDI. Perceiving the level of security as negative can be attributed to the fact that $86 \%$ of the respondents had suffered from crime, hence making the Chinese SMEs to feel very insecure in South Africa. Xenophobia is nowadays a big issue in South Africa as many innocent foreigners have been murdered while enormous properties of the victims have also gone down the drain [22]. This situation must have had an influence on the Chinese SMEs to feel the external environment of South Africa to be xenophobic.

Language barrier (3.46) was perceive as slightly negative but it had the highest standard deviation of 1.66 implying that the respondents were inconsistent on how they perceive the issue of the language barrier. On the contrary, racism had the smallest standard deviation of 1.35 and the majority of respondents perceive racism to be negative (2.59) thus indicating that the respondents were consistent on how they perceive the issue of racism.

On the whole, most of the issues in the socio-cultural environment were perceive as negative. As a result, the average mean of the sociocultural factors was 3.05, implying that the socio-cultural environment in South Africa was perceive by the Chinese SMEs as negative.

Table 4 represents how the respondents feel about the legal system in the external environment of South Africa.

From Table 4, the respondents perceived the legal system as negative as all the mean values of the factors listed under the legal system were perceived negatively by the respondents. This ranges from confidence in the legal system (3.70) to cost of legal services (2.36). Also, in terms of number of responses, most of the respondents were negative to all the issues relating to the legal system. The issue of "cost of legal service" had the highest number of respondents (73) who were negative about the issue. This shows that most of the respondents feel the legal services are expensive and difficult to get. The respondents also had negative feelings about the time to get court judgement (3.07) and the courts protect the guilty (2.99). This implies the courts in the RSA are ineffective as they are slow to give judgements and are perceive of not taking hard decisions on criminals.

\begin{tabular}{|c|c|c|c|c|c|c|}
\hline & Negative & Neutral & Positive & Mean & $\begin{array}{c}\text { Rank } \\
\text { mean }\end{array}$ & $\begin{array}{c}\text { Std } \\
\text { Dev }\end{array}$ \\
\hline $\begin{array}{c}\text { Legal Systems } \\
\begin{array}{c}\text { Confidence in the legal } \\
\text { system }\end{array}\end{array}$ & $1-3$ & 4 & $5-7$ & 3.20 & & 1.41 \\
\hline Law enforcement & 43 & 25 & 25 & 3.57 & 2 & 1.47 \\
\hline Execution of court orders & 50 & 26 & 19 & 3.49 & 3 & 1.33 \\
\hline Access to legal assistance & 47 & 30 & 19 & 3.28 & 4 & 1.46 \\
\hline $\begin{array}{c}\text { Response from police } \\
\text { services }\end{array}$ & 60 & 20 & 16 & 3.11 & 5 & 1.42 \\
\hline $\begin{array}{c}\text { Time to get court } \\
\text { judgments }\end{array}$ & 56 & 34 & 5 & 3.07 & 6 & 1.28 \\
\hline Courts protect the guilty & 60 & 24 & 12 & 2.99 & 7 & 1.55 \\
\hline Cost of legal services & 73 & 20 & 3 & 2.36 & 8 & 1.23 \\
\hline
\end{tabular}

7 point Likert scale: 1 -very negative and 7-very positive.

Table 4: Perception about the legal system.

\section{T-test}

T-test were used to test whether there were significant differences in the mean scores of the external environmental factors (economic, political, socio-cultural and legal factors) with regard to demographics such as years of operation, number of employees and SMEs who will or will not invest again in the RSA.

Figure 3 presents the differences in the mean scores of SMEs with $\leq 6$ years of operation and SMEs with $>6$ years of operation with respect to the four main environmental factors; economic, political/ institutional, socio-cultural and legal factors. The results are based on a 7-point Likert scale: 1-very negative, 7-very positive and 4-neutral.

The results in Figure 3 shows that both SMEs with $\leq 6$ years of operation and SMEs with $>6$ years of operation perceive the economic factors to be neutral while both groups negatively perceive the political/ institutional, socio-cultural and legal factors. Notwithstanding, it was noticed that SMEs who have been operating for more than 6 years perceive the political/institutional, socio-cultural and legal environment slightly more negative than SMEs with less or equals to 6 years. Overall, both groups perceive the external environment of South Africa to be negative. The T-test result indicated that there were no 
Citation: Ngam EF (2017) The Perception of the External Investment Environment of South Africa: The Case of Chinese SMEs FDI. J Bus Fin Aff 6: 282. doi: $10.4172 / 2167-0234.1000282$

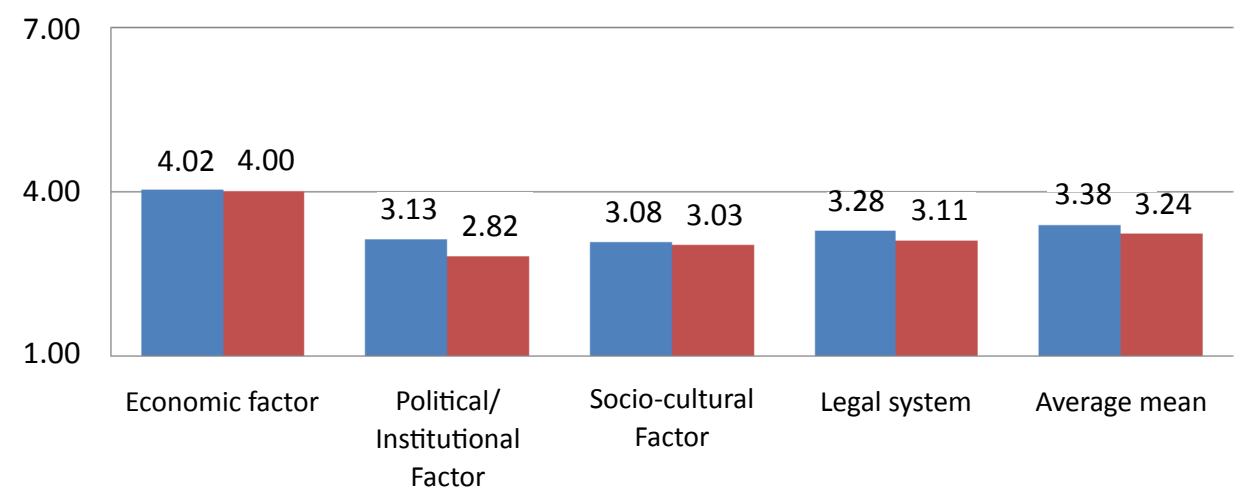

- Mean of SMEs with $\leq 6 y$ years of operation $\quad$ Mean of SMEs with > 6years of operation

Figure 3: Differences in mean score of SMEs with $\leq 6$ years of operation and SMEs with $>6$ years of operation.

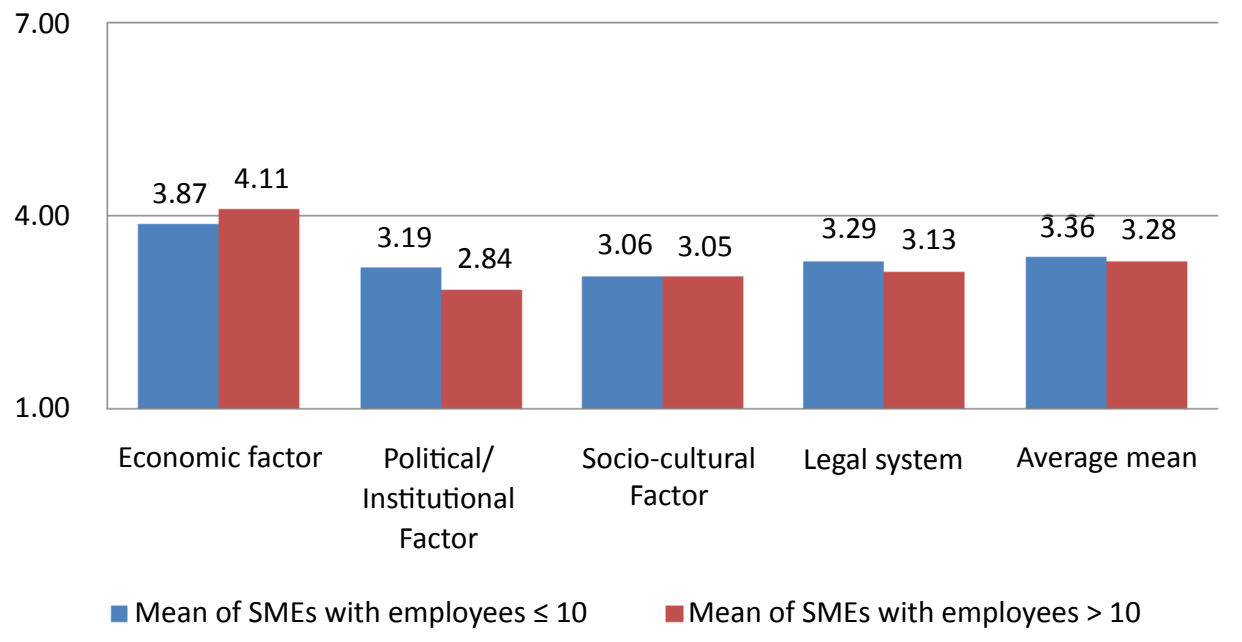

Figure 4: Difference in the mean score of SMEs with $\leq 10$ employees and SMEs with $>10$ employees.

significant differences in the mean scores of SMEs with $\leq 6$ years of operation and SMEs with $>6$ years of operation with respect to the four main environmental factors; economic, political/institutional, sociocultural and legal factors. This therefore implies that the Chinese SMEs perceive the economic, political/institutional, socio-cultural and legal factors in a similar way, no matter how long they have been operating in the RSA.

Figure 4 presents the difference in the mean scores of SMEs with $\leq$ 10 employees and SMEs with $>10$ employees with respect to the four main environmental factors. The results are based on a 7-point Likert scale: 1 -very negative, 7 -very positive and 4-neutral.

From Figure 4, SMEs with less than or equals to 10 employees perceive the four external factors negatively while SMEs with more than 10 employees perceive the economic environment positively but were negative towards the political/institutional, socio-cultural and legal factors. Nevertheless, on average, the bigger SMEs (i.e., SMEs with $>10$ employees) perceive the external environment (3.28) more negatively than SMEs with $\leq 10$ employees (3.36). This therefore pose a problem to the economic growth of South Africa as the bigger SMEs who are capable of increasing employment, reduce poverty, increase foreign currency and improve balance of trade, are the ones having a more negative perception about the business environment in the RSA. This implies that the bigger foreign SMEs could be on the verge of exiting the South African environment because of dissatisfaction or they do not see any prospects of it improving.

However, the T-test conducted indicated that there were no significant differences in the mean scores of SMEs with $\leq 10$ employees and SMEs with $>10$ employees with respect to the four main environmental factors. This implies that, although the bigger SMEs are slightly more negative, there is no significant difference in their perception.

Table 5 shows the T-test results for the difference in the mean score of SMEs who will invest again and SMEs who will not invest again with respect to the economic, political/institution, socio-cultural and legal factors.

It was interesting to note that SMEs who were willing to invest again had a negative feeling towards all the four main external factors while SMEs who were not willing to invest again had a positive feeling towards the economic factors but perceive the rest of the three main factors negatively. However, the T-test results show a significant 


\begin{tabular}{|c|c|c|c|c|}
\hline External Factors & No. items & $\begin{array}{c}\text { Decision } \\
\text { to invest } \\
\text { Mean }\end{array}$ & $\begin{array}{c}\text { Decision not } \\
\text { to invest } \\
\text { Mean }\end{array}$ & $\begin{array}{c}\text { T-test } \\
\text { significance }\end{array}$ \\
\hline Economic Factor & 8 & 3.94 & 4.15 & .241 \\
\hline $\begin{array}{c}\text { Political/Institutional } \\
\text { Factor }\end{array}$ & 5 & 3.18 & 2.61 & .009 \\
\hline Socio-cultural Factor & 15 & 3.08 & 3.00 & .607 \\
\hline Legal Factor & 8 & 3.40 & 2.81 & .003 \\
\hline Average mean & & 3.40 & 3.14 & \\
\hline
\end{tabular}

(Sig at $0.05 ;$ 2-tailed)

Table 5: T-test for the difference in the mean score of SMEs who will invest again and SMEs who will not invest again.

difference in the mean score of political/institutional factors and legal factors. The significant differences imply that SMEs who were not willing to invest again perceive the political/institutional factors $(2.61$ versus 3.81) and legal factors (2.81 versus 3.40) more negatively than SMEs who were willing to invest again. These results emphasize that those not willing to invest again in South Africa base their decision not on economic factors, but on the political/institutional environment and legal systems in the country.

\section{Discussion}

The findings in this study showed that the foreign direct investment of Chinese SMEs in the Free State perceive the external investment environment of South Africa to be unfavourable to foreign businesses. This is in accordance to the fact that of the 36 factors (items) in the external environment that were being studied, only 6 were perceived positive with the factors being either socio-cultural or economic factors. These factors were infrastructure (4.99), telecommunications (4.99) good financial/banking systems (4.85), economic growth (4.63), exchange rate (4.14) and standard of living (4.10). The rest of the factors were perceived negatively with all the political/institutional factors (2.98) and legal factors (3.20) being perceived as negative, implying that the respondents are not satisfied with the political/institutional environment and are not confident in the legal system of the RSA. Crime (1.70), theft (2.01), labour union (2.10) and security (2.11) were the most serious issues impacting negatively on the external business environment of South Africa. These factors causing the investment environment for FDI less favourable could be blame for the fact that South Africa receives only a small share of global FDI even though it has a strong economy, good infrastructure and sound economic policy relative to other African countries.

Chinese SMEs who were willing to leave South Africa said crime was their main reason for wanting to leave as $52 \%$ of them indicated crime as their motive for leaving. Crime is seen as having a huge impact on foreign businesses operating in South Africa. The high crime rate needs to be reduced if South Africa wants to improve its external environment and attract more efficient FDI. To solve this, government can improve upon its policies by ensuring better police visibility, increase area coverage and quick response rate. It can also fight crime by making the legal system more efficient so that criminals are promptly arrested and punished.

With majority of the respondents (68) indicating that labour regulations impact their businesses negatively implies that they are seen to be increasingly affecting both local and foreign businesses operating in South Africa. The labour regulations in South Africa are seen to be very rigid and not flexible as it is very difficult to hire and to fire employees. It is advisable that the government do redesign its labour regulations to make it more flexible. Chinese SMEs were negative about the legal system in South Africa. Government needs to shorten the long procedures and duration of court judgments, and reduce the cost of legal services and the accessibility of legal assistance if it wants to improve the efficiency of the legal system.

The T-test results with respect to the length of operation imply that the longer the respondents operate in the RSA, the higher the possibility for them to encounter labour dispute \& strike and higher cost of labour. This could therefore cause the foreign businesses to exit South Africa early, thus preventing the country from benefiting from positive FDI spillovers which comes with long-term investments. Also, the T-test results with respect to the size of business showed that the bigger foreign businesses are more dissatisfied with the tax system and could hinder them from expanding or could influence them to exit the RSA, thus increasing unemployment in the country.

\section{Conclusion}

The high levels of poverty, income inequality and unemployment are major issues impacting the economic growth of South Africa. Pahad [23] acknowledged that South Africa's social-economic goals are to reduce inequalities, reduce wealth and asset gaps between rich and poor, and reduce unemployment. However, one way of solving these issues is to encourage more foreign SMEs as they are capable of providing investment injections in various sectors of South Africa's economy, such as agriculture, industry, education, and health. Likewise, these foreign SMEs can help eradicate poverty, improve employment and reduce income inequality and wealth disparity between the rich and poor.

The external business environment of South Africa was perceived as predominantly negative by the Chinese SMEs with crime, theft, labour unions, security and labour disputes \& strikes being perceived most negatively by the Chinese SMEs. Also, it was noted that the Chinese SMEs indicated on average that the external factors were impacting their businesses negatively. Crime, corruption, xenophobia and labour regulations were reckoned as the major external factors that impacted their businesses severely. The results go to support the fact that the government is not performing well to fight against crime, control corruption and xenophobia as well as manage the labour regulations. The Chinese SMEs indicated that crime had a negative impact on their business as $86 \%$ of them had suffered from crime. With many foreign businesses and even international bodies complaining about crime in South Africa, the country has to take drastic measures to reduce crime.

The purpose of this study was to investigate the perception of the external investment environment of South Africa by the foreign direct investment of Chinese SMEs in the Free State province. The findings in this study indicated that the perception about the external environmental factors and its impact on foreign businesses are greatly influencing the decision of foreign investors to invest in South Africa. From these empirical findings the study was able to conclude that most Chinese SMEs call attention to the fact that the business environment in South Africa is relatively poor, while others emphasised that they will not re-invest in South Africa, if they were given the opportunity to decide today.

\section{References}

1. Mian M, Alam Q (2006) Foreign Direct Investment and Development: The Bangladesh Scenario. Monash Business Review 2: 1-9.

2. Dunning JH (1993) Multinational Enterprises and the Global Economy. (2 edn.), Harlow, Essex: Addison-Wesley Publication Company. 
Citation: Ngam EF (2017) The Perception of the External Investment Environment of South Africa: The Case of Chinese SMEs FDI. J Bus Fin Aff 6: 282. doi: $10.4172 / 2167-0234.1000282$

Page 9 of 9

3. Oman C (2000) Policy Competition for Foreign Direct Investment: A study of Competition among Governments to Attract FDI. Paris: OECD.

4. Naudé WA, Krugell WF (2003) Foreign investment in Africa: Do institutions and geography matter? Conference of the Economic of South Africa, Somerset West.

5. World Economic Forum's (WEF) (2016) Global Competitiveness Report for 2015/16.

6. Gama J (2004) Foreign direct investment in South Africa. Department of Mercantile Law. University of Pretoria.

7. Anyanwu JC (2006) Promoting of Investment in Africa. African Development Bank Review. The Author Journal Compilation, pp: 42-71.

8. Clarke GRG, Eifert B, Habyarimana J, Ingram M, Kapery W, et al. (2007) South Africa: An Assessment of the Investment Climate.

9. World Bank Institute (2003) Removal of Administrative Barriers in the Context of Legal and Regulatory Reforms: Case Studies and Best International Practices.

10. Wei SJ (1997) How Taxing is Corruption on International Investors? National Bureau of Economic Research.

11. Luiz J (2006) Managing Business in Africa: Practical Management Theory for an Emerging Market. Cape Town: Oxford University Press.

12. Hallward-Driemeier M, Scott W, Colin L (2003) The investment climate and the firm: firm-level evidence from China.

13. Mlambo K, Oshikoya TW (2001) Macroeconomic Factors \& Investment in Africa. Journal of African Economies 10: 12-47.
14. Pigato M (2000) Foreign Direct Investment in Africa: Old Tales and New Evidence. World Bank, Washington, DC.

15. Wang Z, Swain NJ (1997) Determinants of Inflow of Foreign Direct Investment in Hungary and China: Time-series Approach. Journal of International Development 9: 695-726.

16. Ikiara MM (2003) Foreign Direct Investment (FDI), Technology Transfer, and Poverty Alleviation: Africa's Hopes and Dilemma. African Technology Policy Studies (ATPS) Special Paper Series No. 16.

17. Wei SJ (2000) Natural Openness and Good Government. National Bureau of Economic Research.

18. Yang JYY, Groenewold N, Tcha M (2000) The determinants of foreign direct investment in Australia. Economic Record 16: 45-54.

19. Cooper DR, Schindler PS (2003) Business Research Methods. New York McGraw-Hill.

20. Cooper DR, Schindler PS (2006) Business Research Methods. New York: McGraw Hill Inc.

21. South Africa Economic Outlook (2017) Economic Forecasts from the World's Leading Economists.

22. Kupoluyi A (2017) Why xenophobic attacks persist in South Africa. Vanguard.

23. Pahad A (2008) South-South cooperation and poverty reduction. 